\title{
Anotasi Jurnal Pembinaan Etika Peserta Didik Melalui Pembelajaran Tematik - Integratif di Sekolah Dasar
}

Pendidikan merupakan salah satu aspek yang sangat penting untuk membentuk generasi yang siap mengganti tongkat estafet generasi tua dalam rangka membangun masa depan. Karena itu pendidikan berperan mensialisasikan kemampuan baru kepada mereka agar mampu mengantisipasi tuntutan masyarakat yang dinamis. Perubahan yang terjadi dengan begitu cepat tidak terlepas dari perkembangan teknologi dan ilmu pengetahuan, atau yang lebih dikenal dengan era globalisasi. Etika pendidikan berdasarkan pada sebuah kajian nyata bahwa manusia harus melakukan sesuatu dalam tindakan yang beretika, termasuk di dalamnya proses belajar mengajar dalam dunia pendidikan. Ada kesenjangan yang terjadi sekarang bahwa antara penanaman nilai-nilai yang baik dan benar di sekolah pada proses pendidikan, namun di masyarakat sebagailapangan pendidikan tempat mempraktikkan pendidikan tidak memberikan nilainilai etika yang benar sebagai dasar yang mendidik.

Etika dinyatakan sebagai filsafat moral, yaitu studi yang sistematik mengenai sifat dasar dari konsep-konsep nilai baik, buruk, harus, benar, salah, dan sebagainya. Sementara itu, etika dikelompokkan menjadi dua definisi:

a. Etika merupakan karakter individuDalam hal ini termasuk bahwa orang yang beretika adalah orang yang baik. Pengertian ini disebut pemahaman manusia sebagai individu yang beretika. Etika merupakan hukum sosial.

b. Etika merupakan hukum Etika yang mengatur, mengendalikan serta membatasi perilaku manusia.

Etika berfungsi sebagai penilai, penentu dan penetap terhadap seuatu perbuatan yang dilakukan oleh manusia, yaitu apakah perbuatan tersebut akan dinilai baik, buruk, mulia, terhormat, hina dan sebagainya. Dengan demikian etika tersebut berperan sebagai konseptor terhadap sejumlah perilaku yang dilaksanakan oleh manusia. Sehingga di perlukannya pembinaan etika peserta didik melalui pembelajaran tematik integratif di sekolah dasar dengan melalui penanaman nilai moralitas sejak dini. Praktik pendidikan etika di Sekolah Dasar mengedepankan esensi nilai yang dapat diambil oleh peserta

didik. Pembelajaran tematik-integratif, mengeksplorasi tema-tema terkait lingkungan alam, serta manusia. Pada kelas I, II, dan III keduanya (alam dan kehidupan manusia) 
memberikan makna substansial pada beberapa mata pelajaran, seperti: Bahasa Indonesia, Matematika, Seni Budaya, PPKn, hingga Pendidikan Jasmani Olahraga dan Kesehatan. Pada Kompetensi Dasar yang lebih spesifik, IPA dan IPS dikoordinasi terhadap mata pelajaran yang memiliki peran. danya integrasi Kompetensi Dasar yang diorganisasikan dalam pembelajaran tematik, diharapkan peserta didik dapat memahami makna dari apa yang mereka pelajari.

Pada praktik pembelajaran tematik-integratif kurikulum 2013 di jenjang Sekolah Dasar, peserta didik dituntut untuk paham atas materi, aktif dalam partisipasi pembelajaran. Pembelajaran tematik-integratif dengan memasukan pendidikan etika dimaksudkan agar peserta didik mampu memiliki; budi pekerti, sopan santun serta karakter. Praktiknya dapat diintegrasikan ke semua mata pelajaran yang disampaikan guru dengan suatu tema tertentu. Pembelajaran tematik-integratif dipahami sebagai satu pendekatan dalam pembelajaran dimana memberikan ruang integrasi terhadap kompetensi dari beberapa mata pelajaran. Kompetensi yang demikian kemudian disatukan dalam bentuk tema diharapkan memberikan bermakna kepada peserta didik. Demikian, peserta didik memperoleh pengalaman belajar yang bermakna dan pengetahuannya tidak dibatasi dalam disiplin ilmu tertentu. Pembelajaran diyakini mampu mengembangkan ranah kognitif, afektif, dan juga psikomotor peserta didik dengan seimbang dan menyeluruh. Kenyataan yang terjadi bahwa penanaman nilai-nilai yang baik dan benar di sekolah dalam proses pendidikan, dimasyarakat menjadi tempat mempraktekkan pendidikan.

Referensi :

Mutiani, M., Sapriya, S., Handy, M.R.N., Abbas, E. W., \& Jumriani, J. (2021). Pembinaan Etika Peserta Didik Melalui Pembelajaran Tematik-Integratif Di Sekolah Dasar. EDUKATIF: JURNAL ILMU PENDIDIKAN, 3(3), 704-709. 